\title{
168 million years old "marine lice" and the evolution of parasitism within isopods
}

\author{
Christina Nagler $^{1 *} \mathbb{D}$, Matúš Hyžný $y^{2,3}$ and Joachim T. Haug ${ }^{1,4}$
}

\begin{abstract}
Background: Isopods (woodlice, slaters and their relatives) are common crustaceans and abundant in numerous habitats. They employ a variety of lifestyles including free-living scavengers and predators but also obligate parasites. This modern-day variability of lifestyles is not reflected in isopod fossils so far, mostly as the life habits of many fossil isopods are still unclear. A rather common group of fossil isopods is Urda (190-100 million years). Although some of the specimens of different species of Urda are considered well preserved, crucial characters for the interpretation of their lifestyle (and also of their phylogenetic position), have so far not been accessible.

Results: Using up-to-date imaging methods, we here present morphological details of the mouthparts and the thoracopods of 168 million years old specimens of Urda rostrata. Mouthparts are of a sucking-piercing-type morphology, similar to the mouthparts of representatives of ectoparasitic isopods in groups such as Aegidae or Cymothoidae. The thoracopods bear strong, curved dactyli most likely for attaching to a host. Therefore, mouthpart and thoracopod morphology indicate a parasitic lifestyle of Urda rostrata. Based on morphological details, Urda seems deeply nested within the parasitic isopods of the group Cymothoida.

Conclusions: Similarities to Aegidae and Cymothoidae are interpreted as ancestral characters; Urda is more closely related to Gnathiidae, which is therefore also interpreted as an ingroup of Cymothoida. With this position Urda provides crucial information for our understanding of the evolution of parasitism within isopods. Finally, the specimens reported herein represent the oldest parasitic isopods known to date.
\end{abstract}

Keywords: Cymothoida, Isopoda, Urda, Fossil life habits, Evolution, Fossil parasitism

\section{Background}

Parasitism is a widespread strategy among animals (Metazoa), if not the most widespread one. Most, if not all parasites originated from free-living relatives. Still our understanding of how the evolution of a parasitic lifestyle evolved is not fully understood. It has been suggested that there are morphological, physiological, or ecological pre-adaptations to parasitism [1-4].

For improving our understanding of the evolution of parasitism, insects have been considered to be an especially interesting group. It seems that in various insect lineages clear pre-adaptations, such as elongated mouthparts, can be identified [5]. One model example for studying evolution of parasitism and co-evolution

\footnotetext{
* Correspondence: christina.nagler@palaeo-evo-devo.info

${ }^{1}$ Functional morphology group, Department of Biology II,

Ludwig-Maximilians-University, Großhaderner Strasse 2, 82152

Planegg-Martinsried, Germany

Full list of author information is available at the end of the article
}

between the parasite and host are lice, possibly due to human medical health and livestock health interest. Chewing lice ('Mallophaga'), specialized for a parasitic lifestyle on birds [6], have been proposed to have evolved from a free-living relative [7].

Comparable to lice, an evolutionary origin from free-living relatives, has been reconstructed for other parasitic groups, for example several worms, such as parasitic nematode worms [2, 8], parasitic flatworms [9], acanthocephalan worms [10], but also other groups closer related to mallophagan lice, such as mites [11], or parasitic isopod crustaceans [12].

Isopod crustaceans - woodlice, slaters, pill bugs and their relatives - are very diverse and successful malacostracan crustaceans (the group containing e.g. crabs, lobsters, shrimps, krill and crayfish). Isopods inhabit various habitats, including marine, freshwater and terrestrial environments [12-18]. They have developed various kinds of lifestyles, among them free-living [19], scavenging [20-22] or predatory [23], but also parasitic forms of varying degrees of 
specialization [24-27]. This is nicely exemplified by the isopod ingroup Cymothoida sensu Wägele [12]. Within this group numerous lifestyles have evolved, some quite soon after the appearance of the group [28]. Also, as isopods have potential to be preserved as fossils this group allows a degree of estimation of the appearance of such strategies within Earth history:

- A scavenging lifestyle is known from representatives of Cirolanidae. Fossil representatives of this group, indirectly suggesting a similar lifestyle, have been reported from the Jurassic [21] and Cretaceous [22]. Representatives of Corallanidae and Aegidae have a lifestyle reminiscent of that of a mosquito; one may interpret this as quasi-predatory behavior, yet more precisely it is a temporary parasitic lifestyle; they attach briefly to a host, a fish, only during feeding. An aegiid fossil [29] has been reported from the Late Miocene, indicating a similar lifestyle at this time. Phylogenetic inference would suggest an older origin of a "marine mosquito" strategy.

- Representatives of Cymothoidae feed similarly to aegiid isopods when they are juveniles. Yet, as adults they attach to a host fish permanently. The oldest fossil indicating such a type of parasitism in Cymothoidae has been reported from the Jurassic [30].

- During a specific larval phase, representatives of Gnathiidae feed in a comparable way to representatives of adult Aegidae and juvenile Cymothidae [20,31]. Yet, as adults gnathiid isopods are not parasitic. An ingroup position of gnathiids within Cymothoida is equivocal ([32] vs. [33]). So far no fossils of this lineage have been reported.

- A host change respective to their ontogenetic phase can be observed also in representatives of Epicaridea. Larval epicaridids parasitize small crustaceans, e.g. copepods. Adult epicaridids infest mainly larger crustaceans, some are even quasiendoparasitic. Based on malformations on the host $[24,27]$ or by comparing the life habits of modern relative groups [34], this lifestyle must have been present since the Jurassic.

These examples illustrate not only the diversity of life styles within Cymothoida. They also illustrate different ways of inferring a specific lifestyle in fossils [5]: 1) The most direct case is finding a parasite directly associated with a host [30]. 2) A more indirect way is finding isolated specimens with specific morphologies [34]. More indirect cases are (3) findings of developmental stages with a different lifestyle [35] and (4) teratological changes in the morphology of a host [24].

For 2) functional morphology and comparison to extant relatives can support interpretations of different lifestyles.
Hook-like claws at the end of thoracopods for attachment in an isopod give a clear hint to a parasitic lifestyle in contrast to small, straight and pointed tips that could be used for walking locomotion.

Similarly, also for phylogenetic interpretations of fossils morphological characters, such as details of appendages on the head and thorax are crucial [12, 28, 32]. Currently most fossil isopods are mainly interpreted based on dorsal characters, as ventral morphological characters of most fossil isopods are not accessible [29, 36-38].

Yet, under certain preservation conditions more or less complete fossil isopods can be recovered, preserving ventral details, such as appendages and even appendage sub-structures, such as spines and setae. Numerous such well-preserved fossil isopods have been reported from the Mesozoic, especially from Jurassic Konservat Lagerstätten with exceptional preservation [22, 36, 39-44].

One group of isopods that is regularly found in the Jurassic is Urda. This genus currently includes eight species (see Table 1). So far it has neither been possible to reliably interpret the phylogenetic position of Urda nor its lifestyle as descriptions concentrated on dorsal characters. Yet, some authors have suggested a closer relationship of Urda to parasitic isopod groups, such as Aegidae, Cymothoidae or Gnathiidae (see discussion).

Here we present two specimens of Urda rostrata from the Bathonian (168 mya) of Bethel-Bielefeld (Germany). Specimens were documented with the aid of micro CT and reveal crucial characters indicating that these fossils represent the oldest fossil parasitic isopod known to date. With this they contribute novel information to the evolution of parasitism within Cymothoida.

\section{Methods \\ Material}

We investigated two fossil isopod specimens, both interpreted as representatives of Urda rostrata. Both specimens are preserved in an ironstone-geode and come from Bethel-Bielefeld (Germany). They are therefore interpreted as being of Bathonian age, Middle Jurassic, about 168 million years old. Both specimens were found by K. Lenzer in July 1970 and first reported by Büchner [54];

Specimen 1 (BSPG 2011I50, Figs. 1a-b, d, 3a-c and 6a-e) is $32 \mathrm{~mm}$ long from the anterior end of the functional head to the posterior end of the telson and $8 \mathrm{~mm}$ wide. Specimen 2 (BPSG 2011I51, Figs. 1c and 3d-f) is $20 \mathrm{~mm}$ long from the anterior end of the cephalothorax to seventh thorax segment. Pleotelson is missing.

Additionally two extant specimens of parasitic isopods (Cymothoidae) were used for comparison. For comparisons 
Table 1 Summary of Urda spp. occurrences in literature and their preservation

\begin{tabular}{|c|c|c|c|c|c|}
\hline $\begin{array}{l}\text { Current taxonomic } \\
\text { assignment }\end{array}$ & $\begin{array}{l}\text { Original taxonomic } \\
\text { assignment }\end{array}$ & $\begin{array}{l}\text { Age (stage and range in mya) } \\
\text { after [92] }\end{array}$ & Country & $\begin{array}{l}\text { Reference(s), original } \\
\text { reference indicated by }\end{array}$ & $\begin{array}{l}\text { Preservation group }(1=\text { entire } \\
\text { animal, } 2=\text { anterior portion only } \\
3=\text { posterior portion only })\end{array}$ \\
\hline U. cretacea & U. cretacea $[45]$ & Berriasian, 140-145 & Germany & [45] & 3 (t|ll-plV) \\
\hline U. cretacea & U. cretacea $[45]$ & Berriasian, 140-145 & Germany & {$[45]$} & 2 (ct-tIV) \\
\hline U. cretacea & U. cretacea $[45]$ & Berriasian, 140-145 & Germany & {$[45,46]$} & 1 \\
\hline U. cf. cretacea & U. cretacea [47] & Aptian, 113-125 & Antarctica & [47] & 3 (pll-pt) \\
\hline U. liasica & U. liasica [48] & Toarcian, 174-182 & Germany & [48] & 3 (tVI-pt) \\
\hline U. mccoyi & Palaega mccoyi [49] & Oxfordian, 157-163 & Scotland & {$[37]$} & 1 \\
\hline U. moravica & U. moravica [50] & Bathonian, 166-168 & Bohemia & {$[50,46]$} & 3 (tVI-pt) \\
\hline U. punctata & U. punctata [51] & Tithonian, 145-152 & Germany & {$[51,45,46,52,53]$} & 1 \\
\hline U. rhodanica & U. rhodanica [46] & Callovian, 163-166 & France & {$[46]$} & 3 (tV-pt) \\
\hline U. rostrata. & Urda sp.[54, 55] & Bathonian, 166-168 & Germany & this study & 1 \\
\hline U. rostrata. & Urda sp.[54, 55] & Bathonian, 166-168 & Germany & this study & 2 (ct-tlll) \\
\hline U. rostrata & U. rostrata [51] & Tithonian, 145-152 & Germany & {$[51,45,46,52,53,56,57]$} & 2 (ct-tVIII) \\
\hline U. rostrata & U. "cincta" [57] & Tithonian, 145-152 & Germany & {$[52]$} & 1 \\
\hline U. rostrata & U. "cincta" $[51,57]$ & Tithonian, 145-152 & Germany & {$[52]$} & 1 \\
\hline U. rostrata & $\begin{array}{l}\text { U. "elongata" [51], } \\
\text { U. "cincta" [57] }\end{array}$ & Tithonian, 145-152 & Germany & {$[52]$} & 1 \\
\hline U. rostrata & $\begin{array}{l}\text { U. "decorata" [51], } \\
\text { U. "cincta" [57] }\end{array}$ & Tithonian, 145-152 & Germany & {$[52]$} & 1 \\
\hline U. zelandica & U. zelandica [56] & Tithonian, 145-152 & New Zealand & {$[56]$} & 3 (tVl-pt) \\
\hline Urda sp. & Urda sp. [48] & Pliensbachian, 183-191 & Germany & {$[48]$} & 2 (ct-tlll) \\
\hline Urda sp. & Urda sp. [58] & Aalenian, 170-174 & Switzerland & {$[58]$} & 3 (tVI-pt) \\
\hline
\end{tabular}

of the mouthparts a female of Nerocila acuminata (ZSMA 20159001, Figs. 1f and 4d-e) was used. It originates from Cross Bay, Rovinj, Croatia $\left(45^{\circ} 7.06^{\prime} \mathrm{N} 13^{\circ} 3.99^{\prime} \mathrm{E}\right)$, and is still attached to the caudal fin of a representative of Mugilidae, identified and found by R. Melzer in 2014. Preparation, documentation and methodological proceedings have been described in Nagler and Haug [59]. For comparison of the thoracopods a female of Anilocra physodes (ZSMA 04con034, Fig. 1h) was used. It was collected in the Atlantic $\left(21^{\circ} 19.5^{\prime} \mathrm{N}, 17^{\circ} 13.1^{\prime} \mathrm{W}\right)$ by $\mathrm{L}$. Tiefenbacher in 1975.

\section{Documentation methods}

Specimens were investigated with macro-photography and $\mathrm{x}$-ray micro-CT scanning.

Macro-photography, combined with composite imaging (stacks of images of several adjacent image details) was performed following e.g. [60-62] under crosspolarized light. We used a Canon EOS Rebel T3i camera, either with a Canon EFS (18-55 mm) lens (for overview images) or a Canon MP-E (65 mm) macro lens (for close-up images). Illumination was provided by a Canon Macro Twin Lite MT-24EX flash from the two opposing sides to provide even illumination.
Fluorescence microscopy of the sixth thoracopods of A. physodes was performed on an inverse fluorescence microscope BZ-9000 (BIOREVO, Keyence) with a DAPI filter $(\lambda=358-461 \mathrm{~nm})$ recording auto fluorescence and $10 x$ objective resulting in about $100 x$ magnification. Several focus layers (stacks of images) were recorded.

Stacks of images were processed with the freeware packages CombineZP (Alan Hadley), ImageAnalyzer (Meesoft) and Image (Wayne Rasband). Assembling of stereo images and final processing (levels, sharpness, and saturation) was performed in Adobe Photoshop CS4.

Micro-CT scanning was performed on a Nanotom $\mathrm{m}$ Phoenix (GE Sensing \& Inspection Technologies GmbH). An overview scan of specimen 1 ran 60 min with $140 \mathrm{kV}$ and $60 \mu \mathrm{A}$, resulting in a calculated voxel size of $15.8 \mu \mathrm{m}^{3}$. For specimen 2, the scan took $53 \mathrm{~min}$ with $140 \mathrm{kV}$ and $60 \mathrm{~mA}$, resulting in a calculated voxel size of $16.6 \mu \mathrm{m}^{3}$. Scans were reconstructed to tiff stacks with the built-in software. Tiff stacks were further processed with ImageJ and Osirix 5.8.2 (Antoine Rosset). Surface models and volume renderings of both specimens, of thoracopods of specimen 1 and of mouthparts of specimens 1 and 2 were created ("segmented" or by thresholds) in Osirix. The surface models were further modified and rendered with 


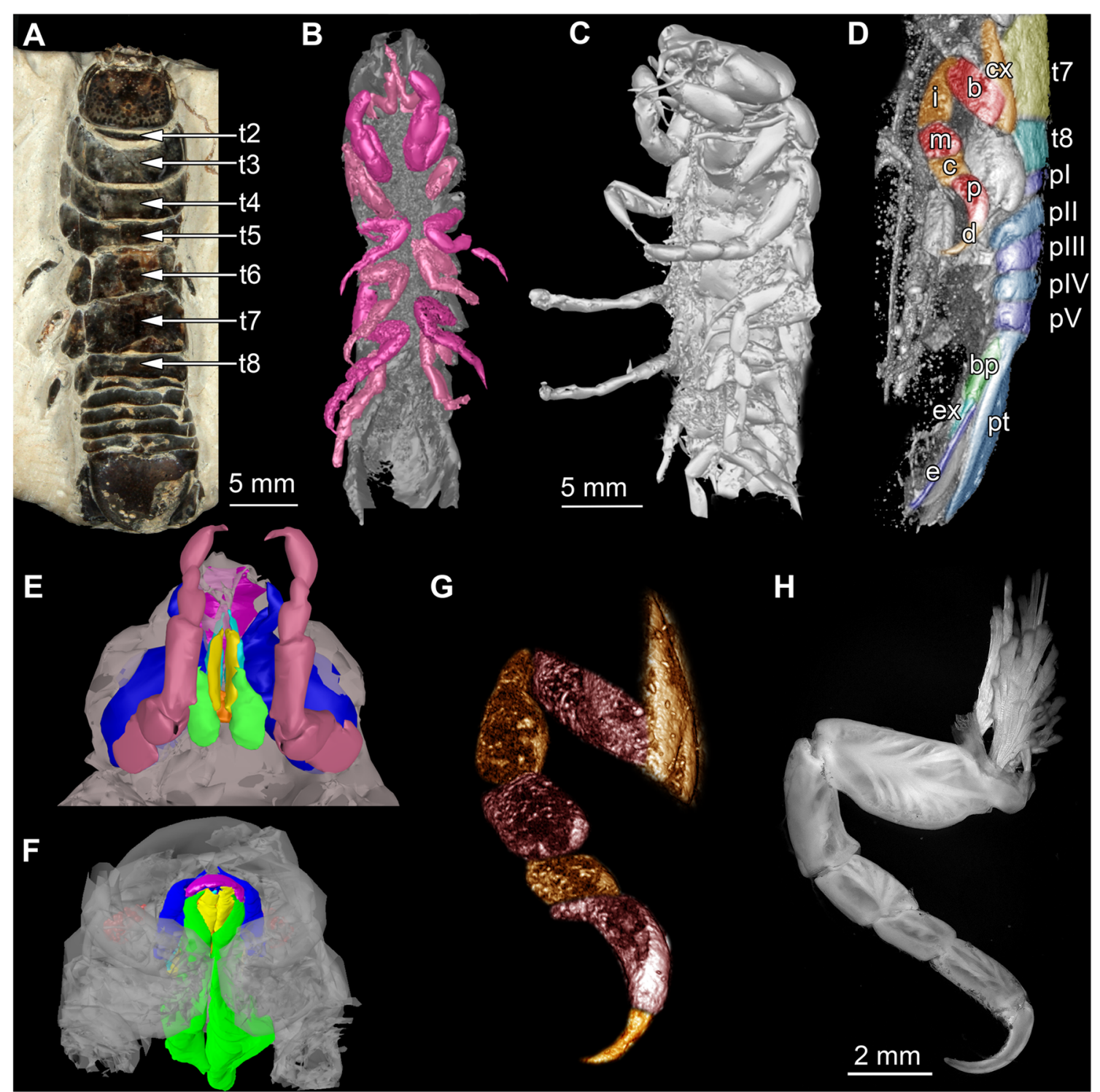

Fig. 1 Fossil specimens and modern counterparts of isopod crustaceans. Urda rostrata: specimen 1 (BPSG 2011150; a-b, d, g); specimen 2 (BPSG 2011151 ; c, e); Nerocila bivitatta (f); Anilocra physodes (h). Color-marks: labrum = purple, mandibles = blue, paragnaths = orange, maxillulae = cyan, maxillae = yellow, maxillipeds = green, thoracopods = pink, thoracopod elements = red and orange, pleon segments = blue and light blue. a Macro photograph with indicated free thorax segments (t2-t8), dorsal view. b-g Reconstructed surface models. b Specimen 1 with colored thoracopods, ventral view. c Specimen 2, ventro-lateral view. d Specimen 1 with colored elements of sixth free thoracopod and segments of thorax, pleon and pleotelson. e Specimen 1, ventral view. f Functional head. $\mathbf{g}$ Sixth thoracopod of specimen 1. h Fluorescence microscopic photography of sixth thoracopod

Blender 2.49 (Blender Foundation). Stereo volume renderings and surface models of specimen 1 and specimen 2 were created ("segmented" or by thresholds) in Osirix. Surface models were further modified and rendered with Blender 2.49 (Blender Foundation).

\section{Presentation method}

The description is focused on preserved structures that give information about the lifestyle of these isopods, i.e. functional morphology of the mouthparts and thoracopods, as these appendages are in direct contact with the host. For a better recognition we present colour-marked images of the important appendages.

\section{Terminology}

Due to the necessity for a uniform terminology among arthropod workers [63], we choose expressions that allow an unambiguous connection of term and structure. Therefore, we use thoracopod II-VIII instead of 'pereiopod 1-7' (or 'peraeopod 1-7'). We also avoid terminology implying serial homology of structures that have independent evolutionary origins; 
hence we use maxillula and maxilla (instead of maxilla one and two).

\section{Results}

Description of the two fossils (specimen 1 BSPG 2011I50; specimen 2 BSPG 2011I51) is focused on preserved structures that give information about the lifestyle of the two isopod crustaceans. Therefore especially the morphology of mouthparts and thoracopods is the focus of the description, as these appendages are in direct contact with the host.

Specimen 1 is more or less complete (Figs. 1a-b, d, g, $3 \mathrm{a}-\mathrm{c}, 4 \mathrm{a}_{6}, 5 \mathrm{a}-\mathrm{b}$, d-e and $\left.6 \mathrm{a}-\mathrm{e}\right)$; specimen 2 is only preserved anteriorly including the first pleon segment; further posterior structures are missing (Figs. 1c, e, 2 and $3 d-f, 4 a_{1-5,7}$, b-c and 5c).

\section{Body organization}

Both specimens three-dimensionally preserved (Figs. 1bc, 3a-f and 6a-e). In visible sclerotised body areas cuticle appears tuberculate. Entire body elongate slightly dorsoventrally flattened, with more or less constant width, but tapering anteriorly and posteriorly.

Body organized into functional head (cephalothorax; seven segments), posterior thorax (pereon; seven free segments) and pleon (five free pleon segments and pleotelson, conjoined structure of pleon segment six and telson).

Functional head consists of a eucrustacean head (ocular segment plus five appendage-bearing segments) and first original thorax segment (Fig. 1e). Head segments form dorsally a single capsulate shield. Head shield sub-rectangular in dorsal view (Fig. 5d). Head segments bear mouthparts ventrally. Each free thorax segment, dorsally forms a sclerotisation, tergite and bears a pair of appendages ventrally (Fig. 5). Tergite of first free thorax segment (thorax segment II) much smaller than those of following segments; not extending as far laterally as functional head or other tergites; very short in anterior-posterior dimensions. Tergite of second free thorax segment (thorax segment III) shows slight anterior indentation medially to match up with smaller anterior tergite. Five pleon segments, each of them roughly as long as one third of the most posterior free thorax segment. Pleotelson shape partly unclear, with a rounded posterior edge in dorsal view; slightly wider than pleon segments (Fig. 6).

\section{Structures of the anterior body}

Description of structures of functional head is largely based on morphology of specimen 2.

Large lateral compound eyes (Figs. 1a, c and 5a-e) situated antero-laterally on functional head; reniform outline. Appendages of post-ocular segments 1 and 2 (antennula and antenna) are not preserved.

Mouthparts (appendages of ocular segment and posterior head appendages) together forming truncated cone (Figs. 1e, 4c and 5a-e); labrum confines the cone from anterior, maxillipeds and thoracopods II seal cone from the posterior. Oral opening is Y-shaped (Fig. 5e).

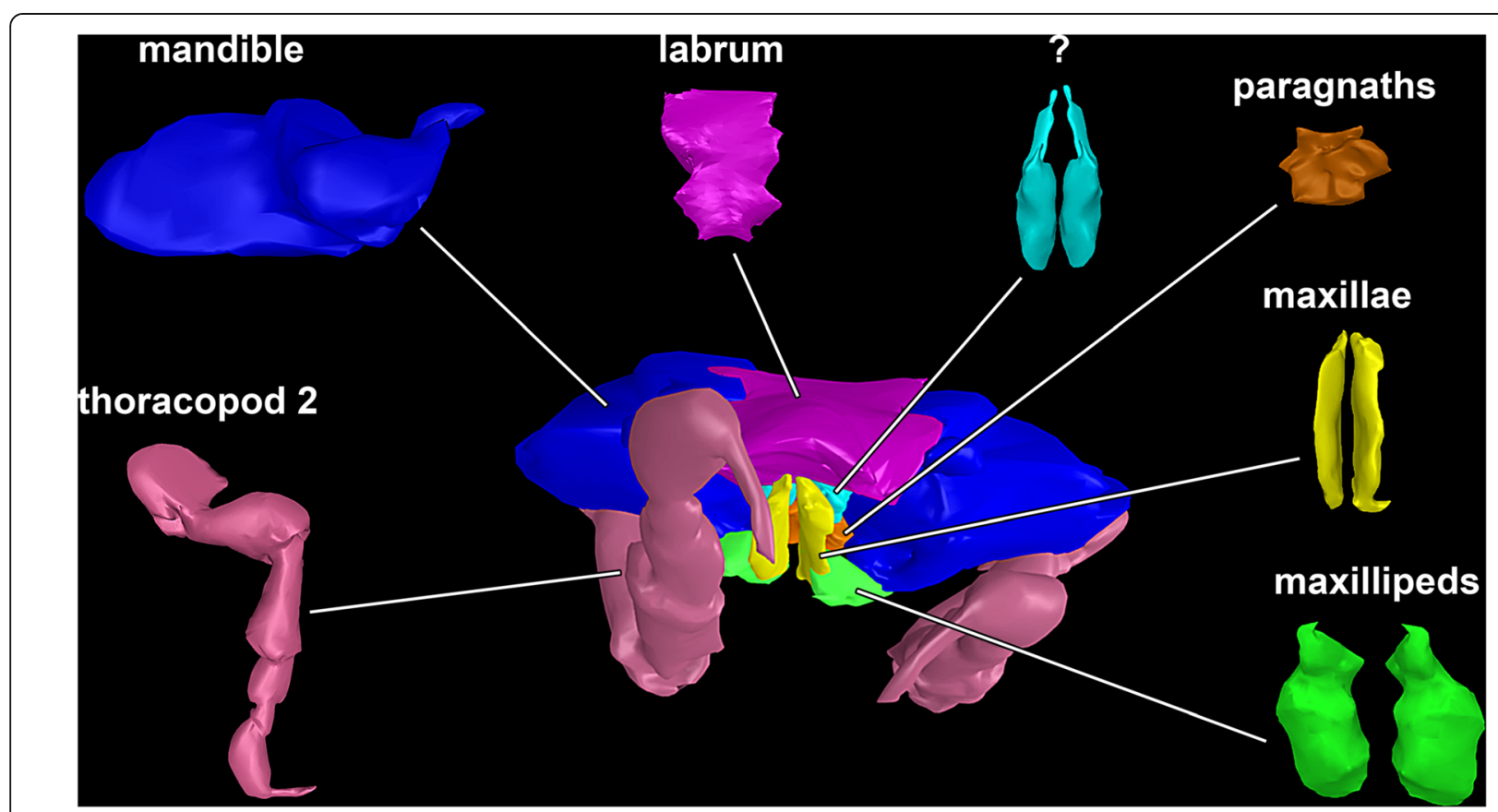

Fig. 2 Reconstructed surface model of the mouthparts of the fossil isopod Urda rostrata (BSPG 2011151). Mouthparts together in anterior view, individual mouthparts in dorsal view. Mouthpart of unclear identity (?) may either represent the maxillula or the distal region of the paragnaths. Not to scale 


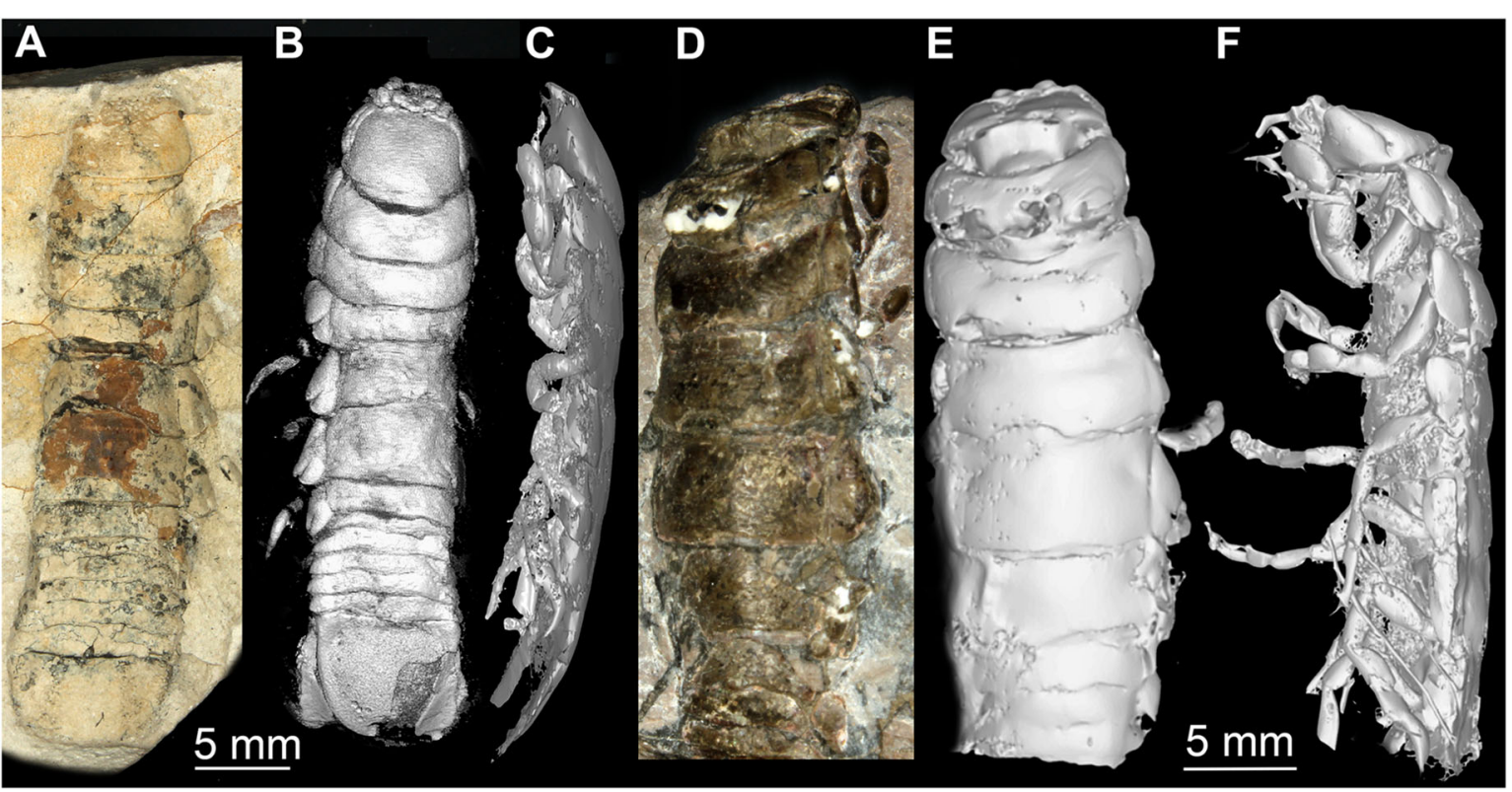

Fig. 3 Macro photographs $(\mathbf{a}, \mathbf{d})$, volume renderings $(\mathbf{b}, \mathbf{e})$ and reconstructed surface models $(\mathbf{c}, \mathbf{f})$ of fossil isopod Urda rostrata. $\mathbf{a}-\mathbf{c})$ U. rostrata specimen 1 (BPSG 2011150). a Counterpart, dorsal view. b Dorsal view. c Lateral view. d-f U. rostrata specimen 2 (BPSG 2011151). d Latero-dorsal view. e Dorsal view. $\mathbf{f}$ Lateral view

Labrum (upper lip, medially fused appendages of ocular segment) elongated; projecting forward from the functional head (Figs. 2, 4a, b , c and 5b-c, e); crescentshaped in distal view (doming anteriorly; functionally dorsally), trapezoid in dorsal view; partly covering remaining mouthparts from anterior.

Appendages of post-ocular segment 3 (mandible) with prominent and stout proximal part (coxa; Figs 2, 4a $a_{1-6}, b_{5}$, $\mathrm{c}$ and $5 \mathrm{~b}-\mathrm{c}, \mathrm{e})$. Coxa rounded rectangular in anterior view. Disto-medially coxa is drawn out into process with massive sharp tip (incisor) at distal end. Distal part (mandibular palp) not preserved (unclear if original condition).

Paired protrusions of the mandibular sternum, paragnaths appear partly preserved (Figs. 2 and $4 a_{1-5}, b_{6}, c$ ); medially conjoined. More or less square-shaped in ventral view, with pointed projections in the middle. Medially forming a funnel, due to a depression (Figs. 2 and $4 b_{6}$ ).

Paired mouthpart of unclear identity slender and elongated with two possible elements or region (large tubeshaped proximal element and thinner flattened distal element); each ending in pointed tip (Figs. 2 and $4 \mathrm{a}_{1-4}$, $\left.b_{4}, c\right)$. Mouthpart is protruding further distally than any other mouthpart. Mouthpart may represent the distal part of the paragnaths or the appendages of post-ocular segment 4 (maxillula).

Appendages of post-ocular segment 5 (maxilla) elongated, chisel-like, (3.5 times as long as broad), flattened in anterior-posterior axis (Figs. 2, 4a $a_{1-3}, b_{3}, c$ and 5b-d), distal end with three spines.
Appendages of post-ocular segment 6 (maxilliped, thoracopod I), broad and stout with two elements (Figs. 1e, 2 and $4 a_{1-2}, b_{2}$, c); distal part bears prominent hook-like spine with a sharp, pointed, recurved tip.

Appendages of post-ocular segment 7 (thoracopod II) with seven elements along main axis. Element 1 (coxa), prominent, stout. Element 2 (basipod) longer, widening distally. Element 3 (ischium) as long as element 2, also widening distally. Element 4 (merus) shorter (50\%), tube-shaped. Element 5 (carpus) shorter (50\%). Element 6 (propodus) swollen, as long as two third of basipod. Element 7 (dactylus) recurved, hook-like (Figs. 2, $4 \mathrm{a}_{1}$, $\mathrm{b}_{1}$, $\mathrm{c}_{1-2}$ and $\left.5 \mathrm{a}-\mathrm{e}\right)$.

\section{Appendages on posterior thorax and pleon}

Description of appendages of post-ocular segment 8-9 (thoracopods II-III) mainly based on morphology of specimen 2 (Figs. 1e, 2, 4a $\mathrm{a}_{1}, \mathrm{~b}_{1}, \mathrm{c}_{1-2}$ and $5 \mathrm{c}$ ), description of appendages of post-ocular segment 10-13 (thoracopods IV-VIII) and post-ocular segment 19 (uropods) based on morphology of specimen 1 (Figs. 1d and 6a-e).

Appendages of post-ocular segment 8-13 (thoracopods II-VIII) each consist of seven elements (similar to thoracopod I); all about twice the size of thoracopod I, largely similar in organization to thoracopod I. All elements 7 (dactyli) at least as long as elements 6 (propodus) (Figs. $1 \mathrm{~g}$ and 6a-d); elongated, strongly curved, hook-like (Figs. 1g, 4b 1 , 5a-e and 6a-d). 

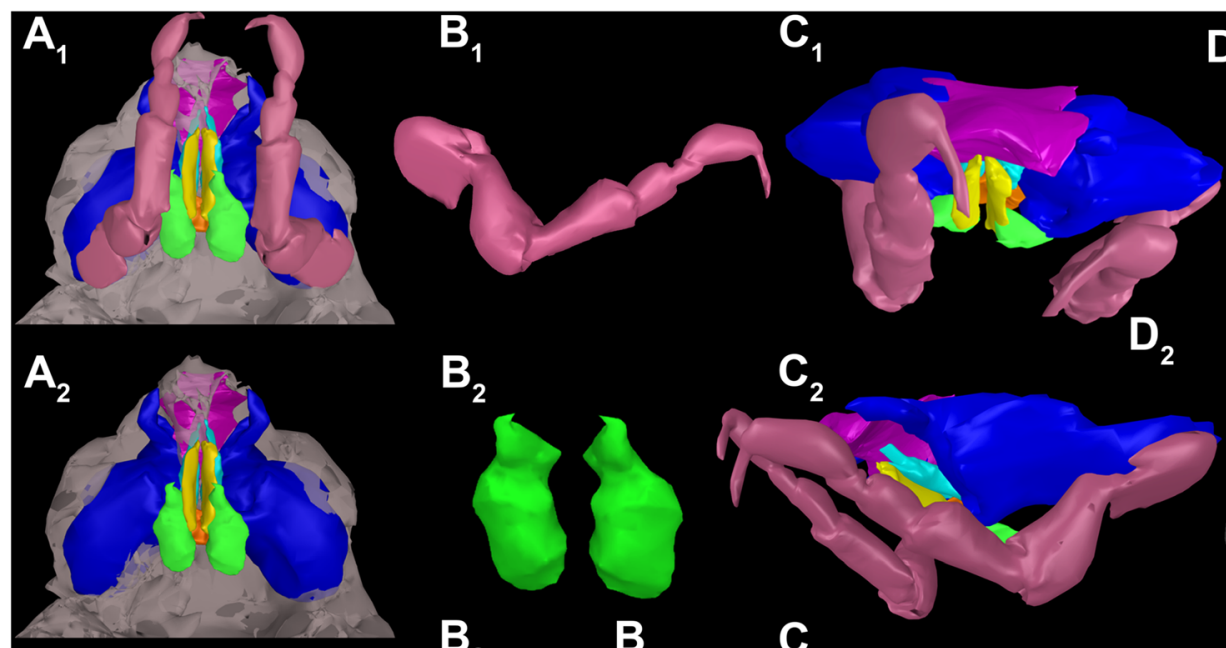

$B_{2}$

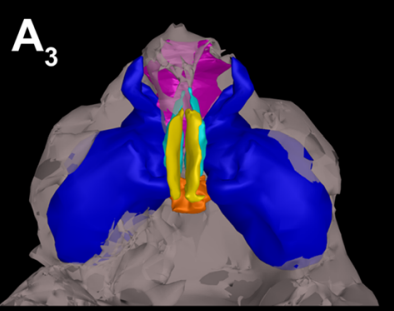

$\mathrm{B}_{3}$
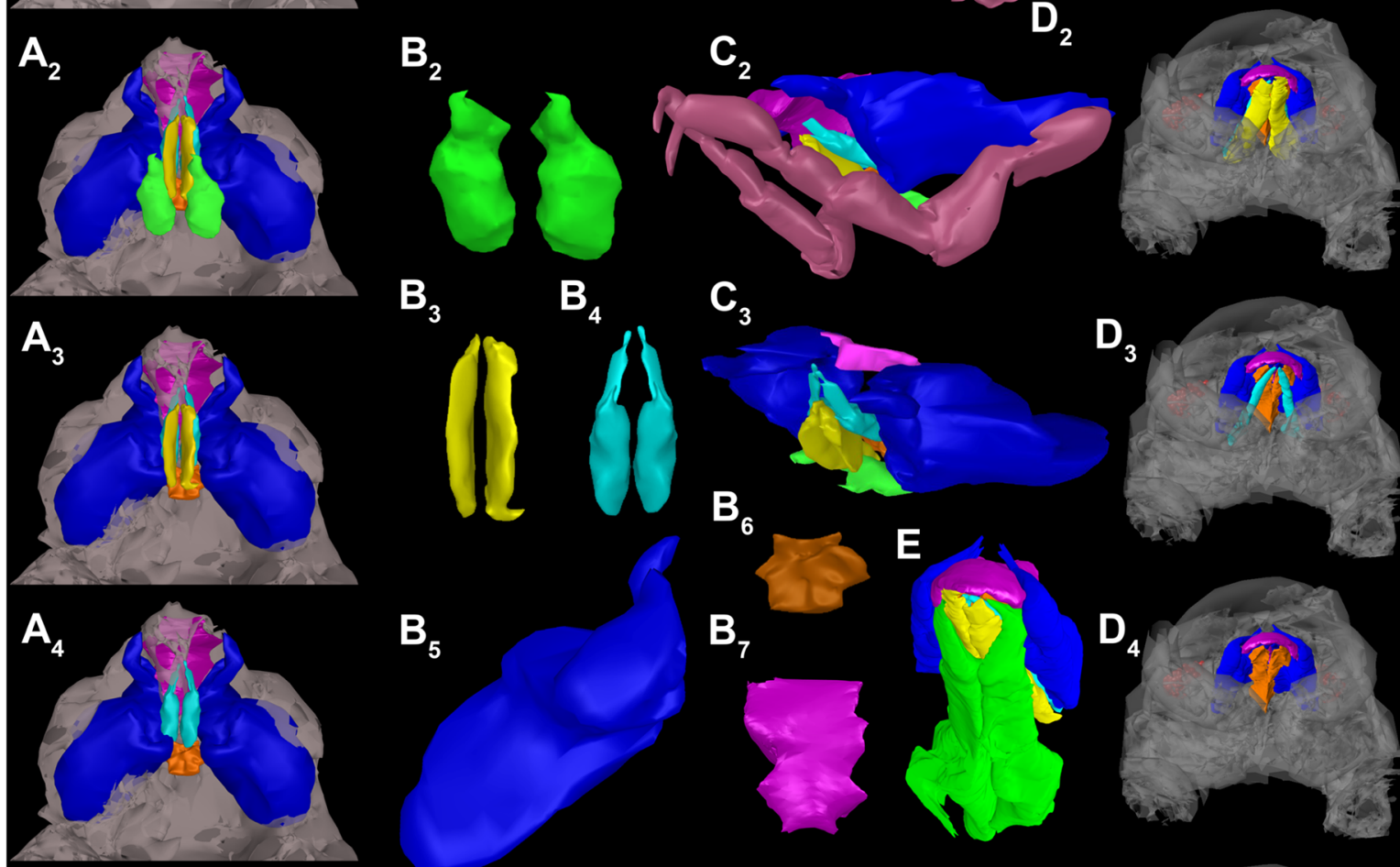

$B_{5}$

$B_{4}$

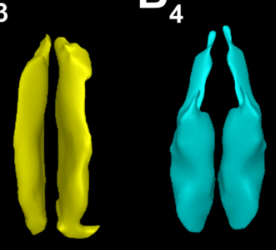

$\mathrm{C}_{3}$
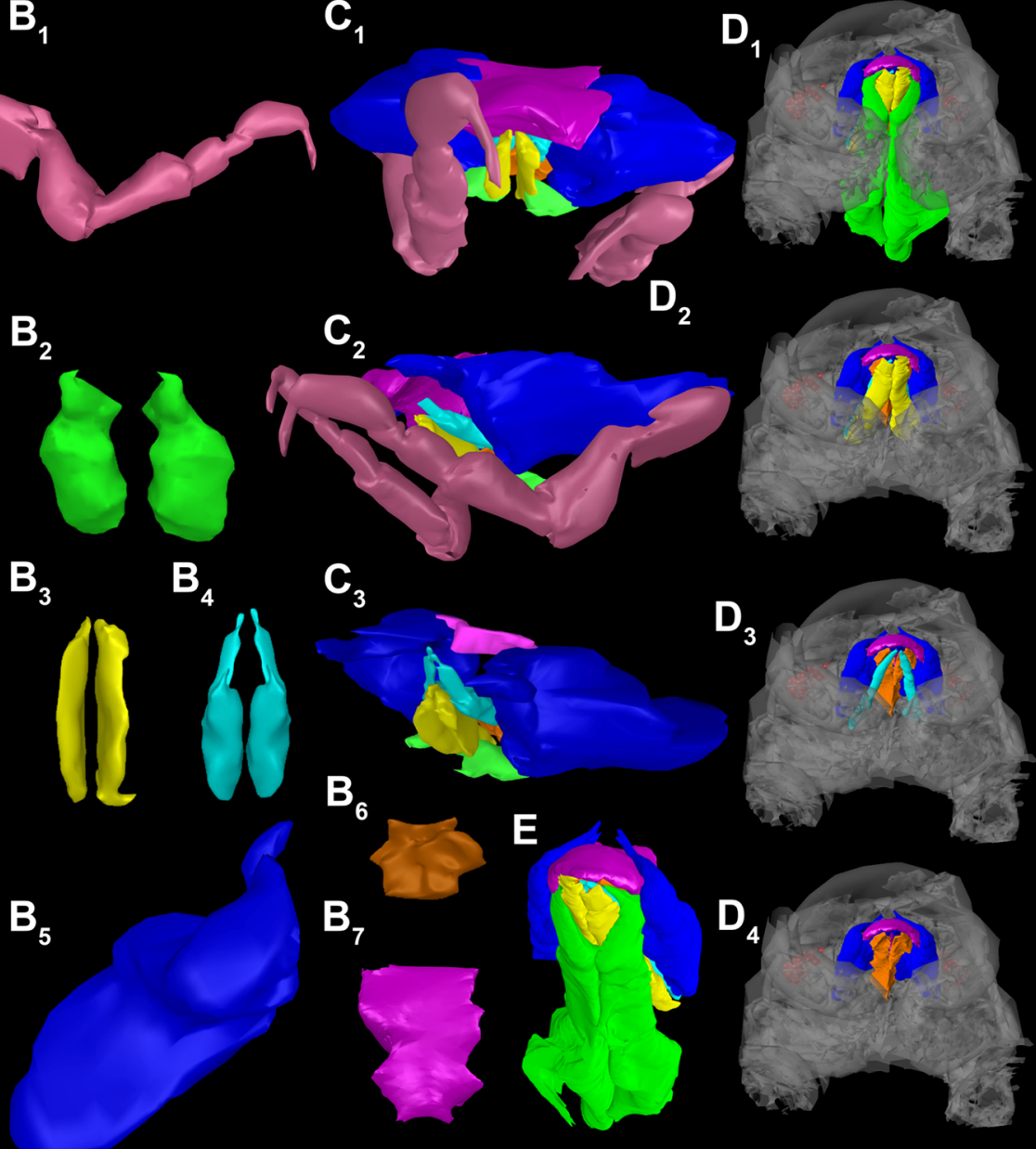

$\mathrm{D}_{4}$
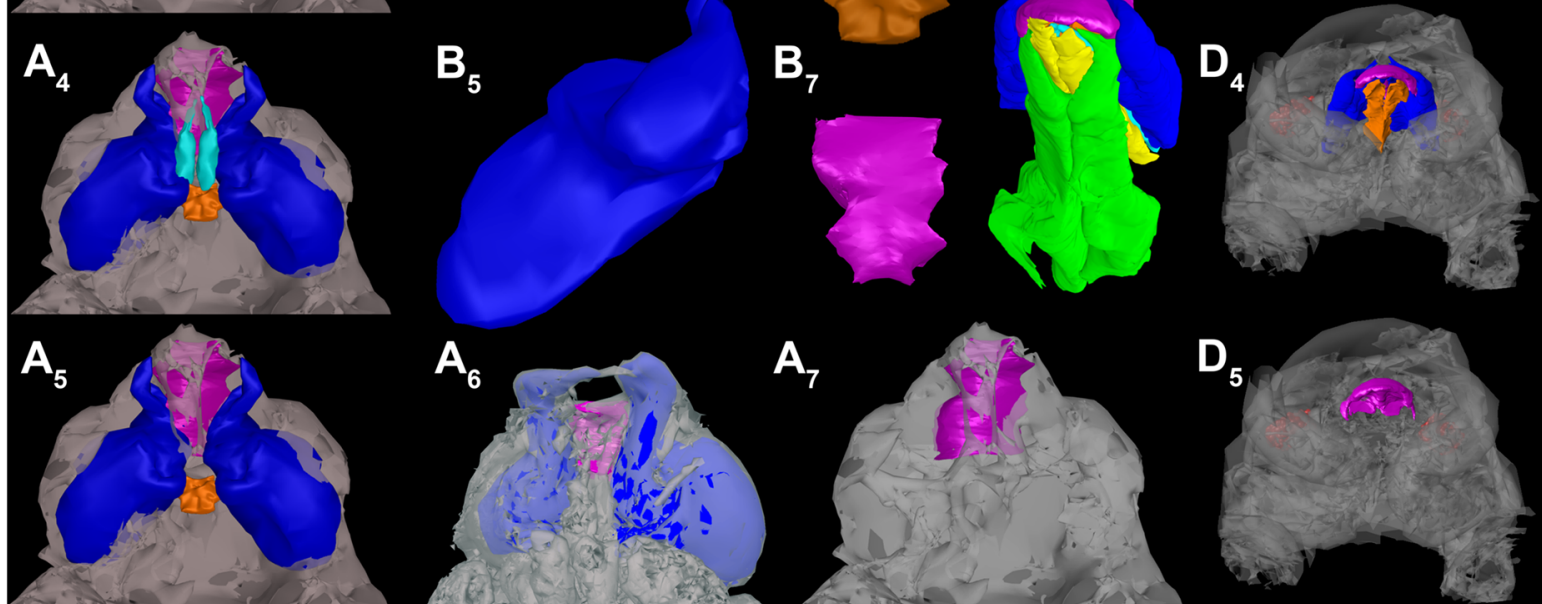

A
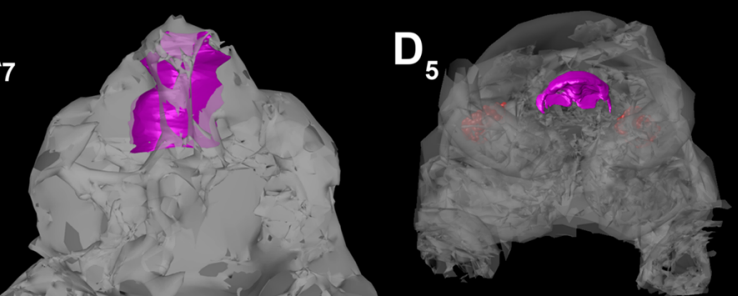

Fig. 4 Reconstructed surface models of the fossil isopod Urda rostrata and modern isopod Nerocila acuminata. Abbreviations: tp = first

thoracopods, $\mathrm{mxp}=$ maxillipeds, $\mathrm{mxa}=$ maxillae, $\mathrm{uc}=$ unclear mouth part, $\mathrm{md}=$ mandibles, $\mathrm{pg}=$ paragnaths, $\mathrm{lb}=$ labrum. $\mathbf{a}_{1-5,7}$ Functional head of U. rostrata specimen 2 (BPSG 2011151) with the first free thorax segment, successively one appendage removed from posterior to anterior, ventral view. $\mathbf{a}_{6}$ Functional head of U. rostrata specimen 1 (BPSG 2011150). $\mathbf{b}_{1-7}$ Mouthparts of U. rostrata specimen 2. $\mathbf{b}_{1}$ ) Tp. $\mathbf{b}_{2}$ ) Mxp. $\mathbf{b}_{3}$ ) Mxa. $\mathbf{b}_{4}$ ) Uc. $\mathbf{b}_{5}$ ) Md. $\mathbf{b}_{6}$ ) Pg. $\mathbf{b}_{7}$ ) Lb. $\mathbf{c}_{1-3}$ Mouthparts of U. rostrata specimen 2, from different angles. $\mathbf{d}_{1-5}$ ) Functional head of N. acuminata, successively one appendage removed from posterior to anterior, ventral view. Not to scale

Thoracopods II-IV rotated roughly $30^{\circ}$ degrees forward, resulting in elements 4-6 (merus, carpus and propodus) being directed diagonally towards the anterior outer edge of body. Thoracopods V-VIII rotated roughly $30^{\circ}$ degrees backward resulting in elements 4-6 (merus, carpus, propodus) being directed diagonally towards the posterior outer edge of body. Dactyli of thoracopods III-IV curved in a ventro-median direction (Figs. 1b, 5c and $6 \mathrm{a}-\mathrm{d})$, dactyli of thoracopods V-VIII more inclined backwards (Figs. 1b and 6a-d).

Appendages of post-ocular segment 14-18 (pleopods $\mathrm{I}-\mathrm{V}$ ) not preserved (Figs. $1 \mathrm{~b}$ and $3 \mathrm{a}-\mathrm{f}$ ). Appendages of post-ocular segment 14-19 (uropods) with basipod carrying two distal rami, endopod and exopod; both similar sized. Uropod forming tail fan with pleotelson (Figs. 1d and $6 c-e)$. 

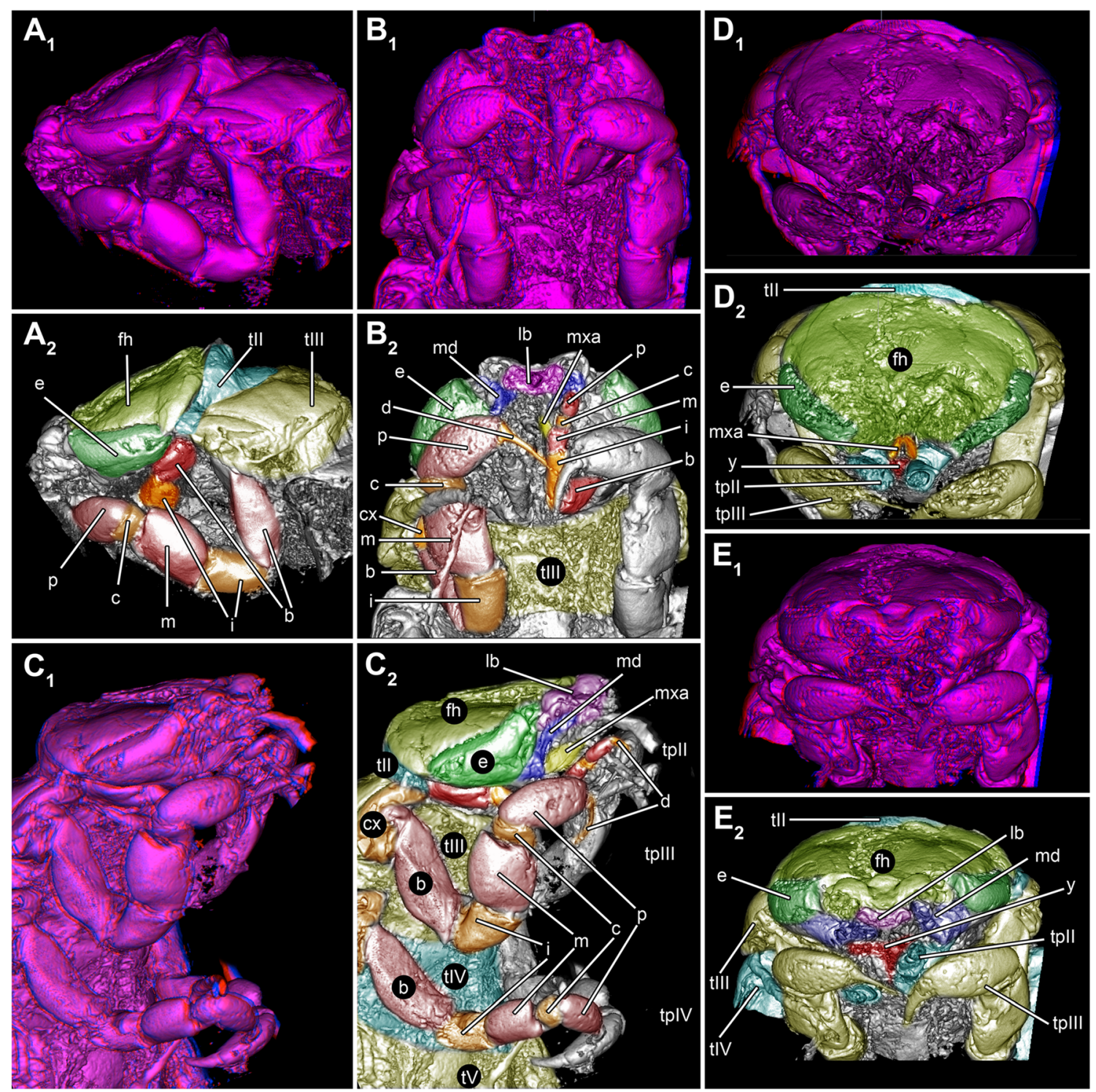

Fig. 5 Stereo images and respectively colour marked versions of volume rendering of the functional head and the anterior region of the thorax of fossil isopod Urda rostrata. Abbreviations: fh = functional head, $e=$ eye, $l b=$ labrum, $m d=$ mandible, $m x a=$ maxillae, $y=y$-shaped mouth opening, $c x=$ coxal plate, $b=$ basis, $i=$ ischium, $m=$ merus, $c=$ carpus, $p=$ propodus, $d=$ dactylus, tII-V = thorax segments $I I-V$, tpll-IV = thoracopods II-IV. a-d Specimen 1 (BPSG 2011150). a 1-2 Lateral view. b1-2 Ventral view. c1-2 Specimen 2 (BPSG 2011151), lateral view. d-e Specimen 1 (BPSG 2011150). d1-2 Anterior view. e1-2 Anterior-ventral view. Not to scale

\section{Discussion}

\section{Inferring the lifestyle}

The lifestyle of representatives of Urda has so far largely been discussed in an anecdotal way. This led, for example, to interpretations of these isopods as scavengers due to a proposed position within Cirolanidae [58] or a swimming lifestyle [64]. Yet, alternative interpretations have also been forward, for example a supposed closer relationship to Gnathiidae [46], Aegidae [39] or Cymothoidae [52, 65]. Such phylogenetic interpretations would indicate an at least partly parasitic lifestyle for representatives of Urda. Support for such interpretations has been largely lacking, as the critical morphological characters, such as the mouthparts and thoracopods, were not visible or only partly preserved $[45-47,58]$. With our finding we can now contribute to this aspect.

\section{Mouthparts}

Modern parasitic isopods (especially within Cymothoida) in general have some of their mouthparts elongated, rotated on their axis distally $\left(45^{\circ}\right.$ from the horizontal axis of the animal), and together forming a more or less tight sucking and/or piercing mouth cone, (Fig. 1f) [59, 66]. 


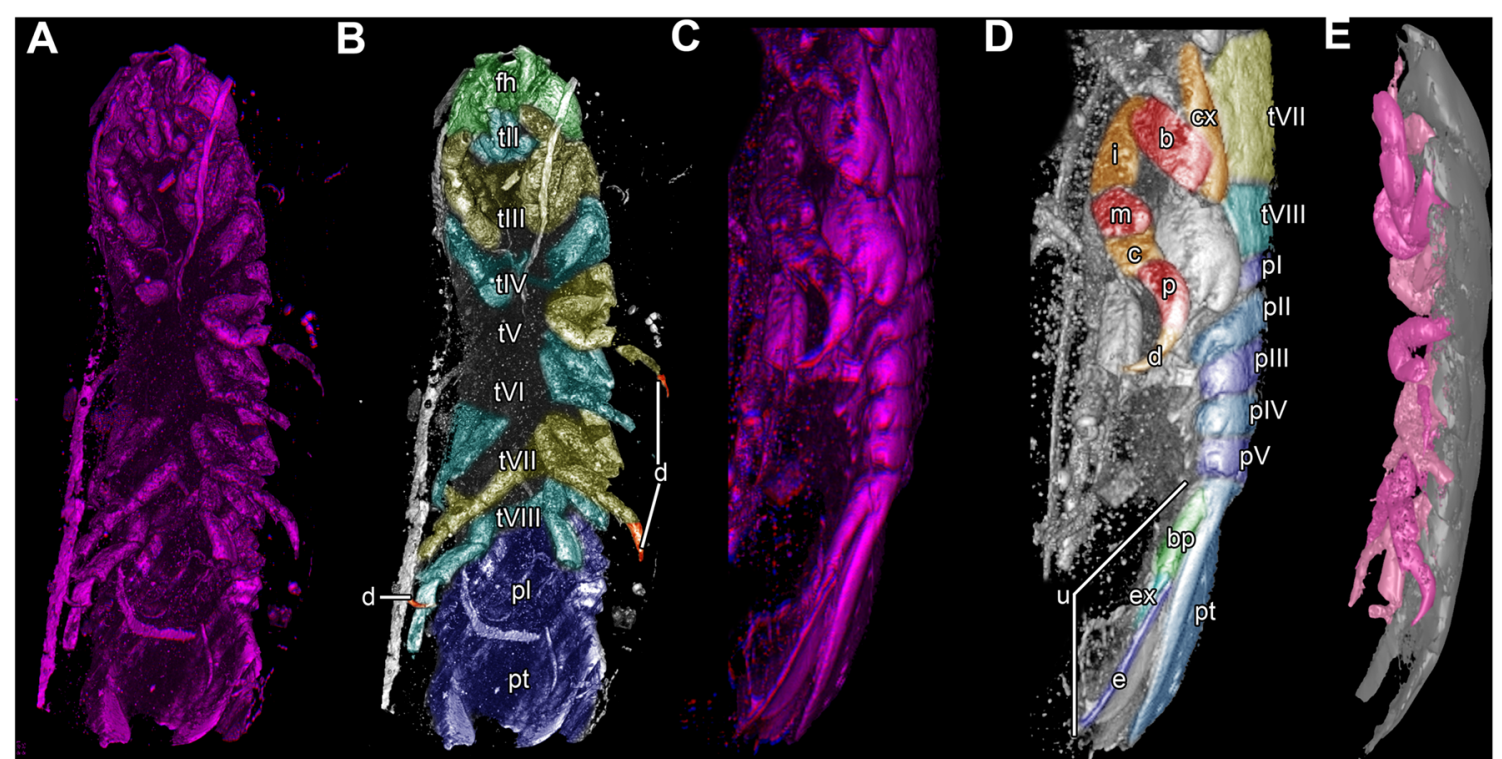

Fig. 6 Stereo images, respectively colour marked versions of volume rendering of the thoracopods of fossil isopod Urda rostrata specimen 1 (BPSG 2011150). Abbreviations: fh $=$ functional head, $t I I-V I I I=$ thoraxsegments $\| I V I I I, c x=$ coxal plate, $b=$ basis, $i=$ ischium, $m=$ merus, $c=$ carpus, $p=$ propodus, $\mathrm{d}=$ dactylus, $\mathrm{pl-V}=$ pleon segments $\mathrm{I}-\mathrm{V}, \mathrm{pt}=$ pleotelson, $\mathrm{bp}=$ basipod, ex =exopod, en =endopod, $\mathbf{u}=$ uropod. $\mathbf{a}-\mathbf{b}$ Ventral view. $\mathbf{c}-\mathbf{e}$ Lateral view. Not to scale

Such an arrangement also appears to be present in the fossil specimens studied here (Figs. 1e, 2, 4c-d and 5a-e).

The forward projecting labrum of the here presented fossils (Figs. 2 and $4 a_{6-7}, b_{7}, c$ ) is similar in shape and position to that of representatives of modern parasitic isopods of the groups Aegidae and Cymothoidae (Fig. 5d-e). In representatives of these groups this type of labrum prohibits loss of fluids when feeding on the host by sealing the mouth cone from the anterior $[59,67]$.

The maxilla and the second mouthpart of unclear identity in the fossil are very elongated and rotated off axis (Fig. 2). Such a type of maxilla is known in representatives of Aegidae and Cymothoidae and act as piercing structures (Fig. $4 \mathrm{~d}_{3}$ ).

The second mouthpart in the fossil is more difficult to interpret as, based on its position, it may represent either the maxillula or parts of the paragnaths. In representatives of Aegidae and Cymothoidae the maxillula is also elongated, as it is in larval, parasitic forms of Gnathiidae [12, 68-70]. The structure seen in the fossil could thus be interpreted as the maxillula. Yet, in adult representatives of Gnathiidae the maxillula is absent and the distal parts of the paragnaths are comparably elongated. This is therefore also a possible interpretation for the fossils.

While the arrangement of the fossils' mouthparts clearly shows that these possess a mouth cone, it differs from that of representatives of Aegidae and Cymothoidae (Figs. If and $4 \mathrm{~d}-\mathrm{e})$. The mouthparts of the fossils appear to form a more loose type of mouth cone (Figs. 1e, 2, 4c and 5a-e). This more loose appearance is caused by 1 ) the absence of a mandibular palp (Figs. 2 and $4 b_{5}$ ) that in representatives of Cymothoidae "grasps" around the labrum further sealing it [59], and 2) the relatively smaller maxillipeds (Fig. 4). The arrangement is therefore more comparable to that in larval representatives of Gnathiidae, where the mouthparts also only form a very loose type of cone [12, 65]. In these larvae the labrum and maxillipeds leave even more areas open than in the fossil.

The mandibles of representatives of Cymothoidae have a triangular blade-like incisor region, to cut pieces of tissues off the host $[59,71,72]$. This is different to the fossils, where the pointed, hooked mandibles were most likely used for piercing movements.

A further important observation is that the first free thorax segment (second thorax segment) is partly incorporated into the functional head (Figs. 1e, 2, 4a 1 , c and $5 \mathrm{a}-\mathrm{e})$. This condition is indicated by the small size of the tergite as well as the far anterior position of the appendage, as well as its size. This appendage may have been used to grasp into the host to provide pressure when inserting the mouthparts into the host. This distantly resembles the condition in Gnathiidae, yet in representatives of this group the segment of the second thoracopod is fully integrated into the functional head [65].

We can conclude that the mouthparts of the fossils investigated here strongly resemble those of modern parasitic forms, such as Aegidae, Cymothoidae and Gnathiidae in many aspects. This makes a parasitic lifestyle, probably on a fish host, for the fossil isopods likely. 


\section{Thoracopods}

The dactyli of all thoracopods of the fossils are strongly curved, i.e. roughly modified into a hook (Figs. 1b, g, 3 and 6). This resembles dactyli of modern parasitic isopods (Fig. 1h). In modern forms, such as representatives of Cymothoidae, such hook-like dactyli are used for attaching to the host $[25,59,73]$. Additionally in modern forms the arrangement of the dactyli is adapted for prohibiting removal from the host [59]. A very similar pattern is seen in the fossil specimens, although the first free thoracopod, tII, is partly incorporated into the head. Still, the dactyli of thoracopods II-V grasp into the host at a $90^{\circ}$ angle to the isopod's body, whereas the dactyli of the remaining thoracopods VI-VIII are more inclined backwards, and in this way strongly resemble modern forms [59].

To summarize, not only the morphology of the mouthparts (Figs. 1e, 2, 4 and 5), but also that of the thoracopods (Figs. 1d, g, 3 and 6) exhibit strong resemblance to similar structures in modern parasites. This similarity indicates a parasitic lifestyle of the fossil specimens studied herein.

Additional, although weaker, hints include: 1) The palaeo-environmental setting of the Bethel-Bielefeld limestone. It was interpreted as a tropical to subtropical back-reef lagoon [74]. Representatives of the obligate parasitic group Cymothoidae are nowadays most diverse in such ecosystems $[32,75]$. 2) The dorso-ventrally flattened body of the fossils (Figs. 1a-d and 3a-f). This body shape is in contrast to, e.g., free-living cirolanids [76]. This can be understood as an additional adaptation for parasitism, reducing water resistance for the host. Similar adaptations are known in modern parasitic forms [77]. 3) The size of the fossils. With at least $30 \mathrm{~mm}$ the specimens are relatively large. Isopods parasitizing fishes have been reported to be larger than most free-living species [78] (except for deep sea forms, such as representatives of Bathynomus).

The eyes of the here described specimens appear well-developed. With this they give no additional indication for a reduced visual capability, as reported for permanently attached parasitic isopods [67, 73]. Together with the appendages that are clearly modified for parasitism we suggest a lifestyle similar to modern representatives of juvenile Gnathiidae. The animal would have attached to a host for a longer time (more or less permanently), but feed on the host only for a short time. With this the overall behaviour of the fossils could be compared to a mallophagan louse. Hence, the fossils are a kind of "marine mallophagan".

\section{Evolution of parasitism within Cymothoida}

Historically, Urda has been interpreted as closely related to Cirolanidae [39, 79], to Gnathiidae [46], to both of these two groups $[47,53,80-82]$, or as a subgroup of Cymothoidae [52, 65].

One major challenge to resolving this issue, besides the lack of knowledge of mouthparts and thoracopods, was a dispute on the body organization of representatives of Urda. Available descriptions vary between five $[45,82]$, six $[54-56,58,80]$ and seven free thorax segments [37, 46, 51, 52]. Our specimens clearly show seven free thorax segments for Urda rostrata (Fig. 1a). Part of the former confusion might have been caused by the rather small tergite of the first free thorax segment.

With our newly observed features we can therefore provide a phylogenetic interpretation of Urda. Additionally, we can provide a new reconstruction of character evolution for parasitic isopods within Cymothoida.

\section{Phylogenetic interpretation}

Cymothoida is a large group within Isopoda, including most (if not all, see below) of the parasitic isopods. There was most likely an evolutionary switch to parasitism that was followed by a large adaptive radiation and thus diversification of the different parasitic isopod groups.

Among the parasitic cymothoidans, it seems well established that Corallanidae is the sister group to all remaining parasitic forms [12, 28, 32, 83]. Corallanidae is united with all remaining forms by the specialization of a hook-like dactylus on thorax appendage II. Such a specialization is absent in free-living closer relatives such as representatives of Cirolanidae, and therefore appears to be an autapomorphy of the group including all the parasites.

The sister group to Corallanidae is a group including Aegidae, Cymothoidae and Epicaridea. This group has been largely accepted as monophyletic. The group is characterized (autapomorphy) by not one, but three hook-like dactyli on thorax appendages II, III and IV. Additionally they share a specialization of the mouthparts, which form a mouth cone allowing piercing and sucking (partly further specialized and reduced in different epicarids).

Epicaridea and Cymothoidae both have more than three hook-like dactyli, indicating a closer relationship between the two, and together being the sister group to Aegidae. Yet, we have not mentioned Gnathiidae. This group has been "shifted around the tree" in numerous studies [12, 28, 32, 33, 73, 83]. In this sense the fossils described here are interesting as they share certain aspects of their morphology with representatives of Gnathiidae and others with representatives of Cymothoidae and Aegidae. Representatives of Gnathiidae share certain morphological aspects with Epicaridea and Cymothoidae: all have the posterior six thoracopods modified for attaching (in contrast to Aegidae, where there are only three). We therefore suggest that Urda and 
Gnathiidae are nested within the other parasitic isopods of Cymothoida.

Yet, six hook-shaped dactyli are restricted to a specific (larval) life stage in Gnathiidae. Also the exact attachment appears modified in Gnathiidae as the propodus appears to be a functional part of the "hook". Still the non-parasitic lifestyle of other life stages and the different attachment structure can be understood as secondary modifications. Gnathiidae and Epicaridea share the absence of the maxillula [73]. We therefore interpret these two as more closely related to each other than either of these two to Cymothoidae.

Urda could thus either represent the sister group of (Epicaridea + Gnathiidae) or of Gnathiidae alone. Similarities of Urda with Aegidae and Cymothoidae would represent plesiomorphies; a less tightly packed mouth cone and possible absence of the maxillula (if the unclear mouthpart represents the paragnaths) would unite Urda, Gnathiidae and Epicaridea. The partial incorporation of the thorax segment II into the head could represent a synapomorphy of Urda and Gnathiidae.

\section{Character evolution}

The proposed phylogeny would lead to a character evolution as follows (Fig. 7):

1) The ground pattern (= reconstructed morphology of the stem species) of Cymothoida (character state transition 1) includes mouthparts indicating a carnivorous mode of feeding [12, 32, 73], thoracopods are of a swimming-type [84]. The stem species was most likely a scavenger or predator on fish.

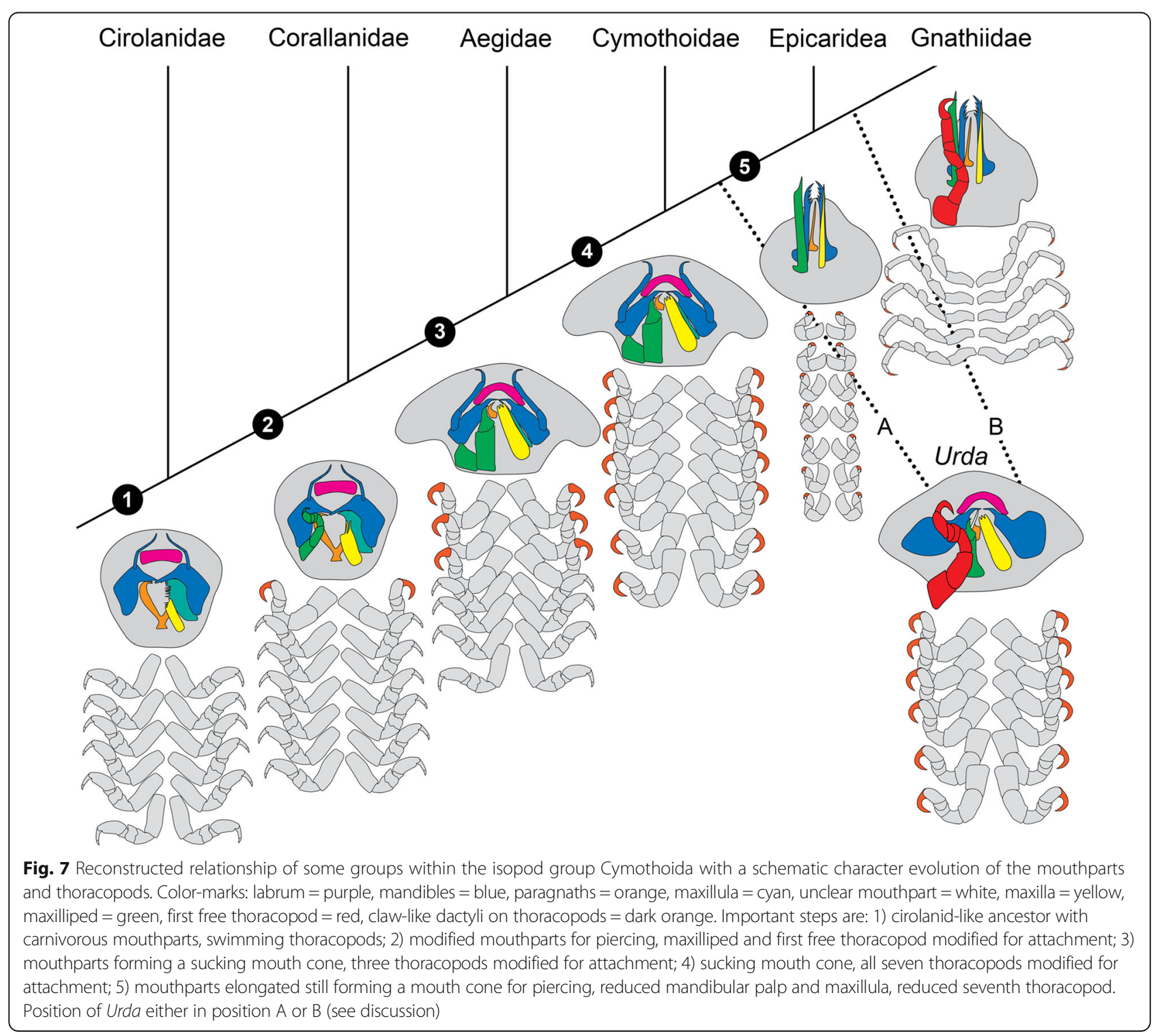


2) The ground pattern of the unnamed sister group to Cirolanidae (including Corallanidae, Aegidae, Cymothoidae, Urda, Gnathiidae, Epicaridea; character state transition 2) is characterized by slightly longer, thinner and more pointed mouthparts that facilitate piercing; but still a slender maxilliped. At least the second pair of thoracopods appears to have a hook-like dactylus with which they attach to fish for temporary parasitism.

3) The ground pattern of the unnamed sister group to Corallanidae (including Aegidae, Cymothoidae, Urda, Gnathiidae, Epicaridea; character state transition 3) is characterized by a further specialization of the mouthparts; these form a sucking mouth cone (sealed by the labrum, paragnath, maxilla, maxilliped, and maxillula and mandible are used for piercing and cutting pieces of the host) [66]. Thoracopods two to five (three pairs of thoracopods) have strong hook-like dactyli $[67,73]$. Adults have retained well-developed eyes [85]. The morphology of the mouthparts and thoracopods is strongly modified for a temporary parasitism on fish, comparable to a "marine mosquito".

4) The ground pattern of the unnamed sister group to Aegidae (including Cymothoidae, Urda, Gnathiidae, Epicaridea, character transition state 4) still includes a mouth cone $[59,66,73]$. Seven thoracopods (II-VIII) are now modified for better attachment to the host with hook-like dactyli $[67,73]$.

5) The ground pattern of the unnamed sister group of Cymothoidae (Gnathiidae, Urda Epicaridea, character transition state 5) is characterized by the lack of the mandibular palp and the maxillula [73]. Also the labrum is smaller and not covering the other mouthparts, resulting in a sucking and piercing mouth cone that is not as tight as in representatives of Cymothoidae of Aegidae. Thoracopods retain the hook-like dactyli.

In summary, the specialized and diverse morphology and parasitic lifestyle of representatives of Epicaridea, Gnathiidae and Urda originated from the scavenging life style in representatives of Cirolanidae. It occurred stepwise via a lifestyle as seen in representatives of Corallanidae, attaching to a fish and feeding on it, the still temporary parasitic lifestyle with already suckingfeeding in representatives of Aegidae and the permanent parasitic lifestyle of for example Cymothoidae. A similar evolutionary reconstruction has been proposed for other parasitic arthropods, such as lice [6]. Modern book lice, supposedly the sister group to true lice, are known to live in nests and pelage of mammals and birds and feed on remains of these larger animals [7, 86, 87]. Modern true lice, e.g. chewing and sucking lice (mallophagan and anopluran respectively) are obligatory ectoparasites on birds and mammals [88]. The ancestors of true lice had simple chewing mouthparts and were free living in the nests of vertebrates (similar to book lice). Later in their evolutionary history, they adapted from associates to parasites by feeding directly from their hosts; hence, representatives of true lice evolved more specialized mouthparts for specific hosts and consequently a large diversity of forms $[5,89]$. Due to the similarity between the evolutionary reconstruction of lice and representatives of Cymothoida and the similar lifestyle of chewing lice and the fossil specimens studied herein, we refer to these fossils and similar behaving isopods as "marine mallophagans".

\section{Conclusion}

We provide here indirect evidence for a case of palaeoparasitology by a 168 million years old isopod. This represents the oldest possible fossil parasitic isopod to date. Furthermore, the fossils contribute important data towards the origin and diversification of parasitism within the isopod group Cymothoida. Parasitism appears to have arisen only once, further diversifying within the group. As these fossils appear deeply nested within the parasitic Cymothoida, the origin of the group and with this of a parasitic lifestyle within isopods must be even older than 168 million years.

\section{Abbreviations}

BSPG: Bavarian state collection for palaeontology and geology; ZSM: Bavarian state collection of zoology

\section{Acknowledgements \\ We thank Martin Nose and Alexander Nützel, Bayerische Staatssammlung für Paläontologie und Geologie (BSPG, Bavarian State Collection for Palaeontology and Geology, Munich) for providing the material of the fossil specimens. We thank Jason Dunlop, Museum für Naturkunde Berlin (Museum of Natural History Berlin), for proofreading the manuscript. Special thanks to Carolin Haug, LMU Munich, for several discussions about the proposed phylogeny of Cymothoida. We want to thank Roland Melzer, Enrico Schwabe and Stefan Friedrich, Zoologische Staatssammlung München (ZSM, Zoological State Collection, Munich) for providing this material of extant specimens. We thank J. Matthias Starck, LMU Munich, Christine Dunkel, Antoinette v. Sigriz-Pesch, LMU Munich and Roland Melzer, ZSM Munich, for their support. We thank all people involved in providing free and low-cost software, such as OpenOffice, CombineZM, Com- bineZP, and Image Analyzer.}

\section{Funding}

CN is gratefully funded by Studienstiftung des deutschen Volkes with a PhDfellowship. MH was supported by VEGA 02/0136/15 and the Slovak Research and Development Agency under APW-0644-10 and APW-0436-12. The German Research Foundation (DFG) under Ha 6300/3-1 kindly funded JTH.

\section{Availability of data and materials}

The microCT dataset of specimen 1 (BSPG2011150) is available from www.morphdbase.de under the accession number C_Nagler_20170221-M130.1 [90] www.morphdbase.de). The microCT dataset of specimen 2 (BSPG2011151) is available from www.morphdbase.de under the accession number C_Nagler_20170221-M-131.1, [91] www.morphdbase.de). 


\section{Authors' contributions}

Conceptualization, CN and JTH; Methodology, CN and JTH; Formal Analysis, $\mathrm{CN}$ and JTH; Investigation, CN, MH and JTH; Resources, BSPG (MN and AN), ZSM (RM, ES and SF), MH; Data Curation, CN; Writing - Original Draft, CN; Writing - Review \& Editing, MH and JTH; Visualization, CN; Supervision, $\mathrm{MH}$ and JTH; Funding acquisition, $\mathrm{CN}, \mathrm{MH}$ and JTH. All authors read and approved the final manuscript

\section{Competing interests}

The authors declare that they have no competing interests.

\section{Consent for publication}

Not applicable.

\section{Ethics approval}

All methods were in compliance with the regulations and guideline of IUCN Policy Statement on Research involving species at risk of Extinction.

\section{Author details}

'Functional morphology group, Department of Biology II, Ludwig-Maximilians-University, Großhaderner Strasse 2, 82152 Planegg-Martinsried, Germany. '2Department of Geology and Palaeontology, Faculty of Natural Sciences, Comenius University, Mlynská dolina, Ilkovičova 6 , 84215 Bratislava, Slovakia. ${ }^{3}$ Geological-Paleontological Department, Natural History Museum Vienna, Burgring 7, A-1010 Vienna, Austria. ${ }^{4}$ GeoBio-Center, Richard-Wagner Strasse 10, 80333 Munich, Germany.

Received: 14 October 2016 Accepted: 16 February 2017

\section{Published online: 09 March 2017}

\section{References}

1. Osche G. Die präadaptation freilebender nematoden an den parasitismus. Zool Anz. 1956;19:391-6.

2. Osche G. Beiträge zur Morphologie, Ökologie und Phylogenie der Ascaridoidea (Nematoda). Z Parasitenkd. 1958;18:479-572.

3. Piekarski G. Neue Ergebnisse parasitologischer Forschung. Naturwissenschaften. 1973;60:139-44.

4. Poulin R. Evolutionary ecology of parasites. Princeton: Princeton University Press; 2011.

5. Nagler C, Haug JT. From fossil parasitoids to vectors: insects as parasites and hosts. Adv Parasit. 2015;90:137-200

6. Johnson KP, Clayton DH. The biology, ecology and evolution of chewing lice. Syst Biol. 2003:53:449-76.

7. Yoshizawa K, Lienhard C. In search of the sister group of true lice: a systematic review of booklice and their relatives, with an updated checklist of Liposcelididae (Insecta: Psocodea). Athropod Syst Phylog. 2010;68:181-95.

8. Blaxter ML, De Ley P, Garey JR, Liu LX, Scheldeman P, Vierstraete A, Vanfleteren JR, Mackey LY, Dorris M, Frisse LM, Vida JT, Thomas K. A molecular evolutionary framework for the phylum Nematoda. Nature. 1998;392:71-5.

9. Littlewood DTJ, Rohde K, Bray RA, Herniou EA. Phylogeny of the Platyhelminthes and the evolution of parasitism. Biol J Linn Soc. 1999:68:257-87.

10. Near TJ. Acanthocephalan phylogeny and the evolution of parasitism. Integr Comp Biol. 2002:42:668-77.

11. Mironov SV, Bochkov AV, Fain A. Phylogeny and evolution of parasitism in feather mites of the families Epidermoptidae and Dermationidae (Acari: Analgoidea). Zool Anz. 2015;243:155-79.

12. Wägele JW. Evolution und phylogenetisches System der Isopoda. Zoologica. 1989;140:1-262.

13. Brusca R, Coelho VR, Taiti S. Isopoda. In: Carlton JT, editor. The Light and Smith manual: intertidal invertebrates from central California to Oregon. Berkley: University of California Press; 2007. p. 503-42.

14. Hornung E. Evolutionary adaptation of oniscidean isopods to terrestrial life: Structure, physiology and behavior. Terr Arthropod Rev. 2011;4:95-130.

15. Kensley B, Schotte M. Guide to the marine isopod crustaceans of the Caribbean. Washington: Smithsonian Institute Press; 1989

16. Kussakin O. Marine and brackish-water Crustacea (Isopoda) of cold and temperate waters of the Northern Hemisphere. Nat Acad Sci Zoo. 1979;122:1-470.

17. Poore GC, Bruce NL. Global diversity of marine isopods (except Asellota and crustacean symbionts). PLoS One. 2012;7:e43529.
18. Sfenthourakis S, Taiti S. Patterns of taxonomic diversity among terrestrial isopods. Zookeys. 2015;2015:13.

19. Kensley B. Estimates of species diversity of free-living marine isopod crustaceans on coral reefs. Coral Reefs. 1998;17:83-8.

20. Lowry JK, Dempsey K. The giant deep-sea scavenger genus Bathynomus (Crustacea, Isopoda, Cirolanidae) in the Indo-West Pacific. In: Richer DFB, Justine J-L, editors. Tropical Deep-Sea Benthos. Paris: Mémoires du Muséum National d'Histoire Naturelle, Paris; 2006. p. 163-92.

21. Polz H. Asselansammlung auf einer Wasserwanze aus den Solnhofener Plattenkalken. Archaeopteryx. 2004;22:51-60.

22. Wilson GD, Paterson JR, Kear BP. Fossil isopods associated with a fish skeleton from the Lower Cretaceous of Queensland, Australia-direct evidence of a scavenging lifestyle in Mesozoic Cymothoida. Palaeontology. 2011;54:1053-68.

23. Wallerstein BR, Brusca RC. Fish predation: a preliminary study of its role in the zoogeography and evolution of shallow water idoteid isopods (Crustacea: Isopoda: Idoteidae). J Biogeogr. 1982;1982:135-50

24. Klompmaker AA, Artal P, van Bakel BW, Fraaije RH, Jagt JW. Parasites in the fossil record: a Cretaceous fauna with isopod-infested decapod crustaceans, infestation patterns through time, and a new ichnotaxon. PLoS One. 2014;9:e92551.

25. Smit NJ, Bruce NL, Hadfield KA. Global diversity of fish parasitic isopod crustaceans of the family Cymothoidae. Int J Parasitol Parasites Wildl. 2014. 3:188-97

26. Trilles J-P, Hipeau-Jacquotte R. Symbiosis and parasitism in the Crustacea. In: Scram F, Vauple Klein C, editors. Treatise on Zoology-Anatomy, Taxonomy, Biology. Leiden: Brill; 2012. p. 239-317.

27. Klompmaker AA, Boxshall GA. Fossil Crustaceans as Parasites and Hosts. In: DeBaets K, Littlewood T, editors. Advances in Parasitology. London: Elsevier; 2015. p. 233-89.

28. Dreyer H, Wägele JW. Parasites of crustaceans (Isopoda: Bopyridae) evolved from fish parasites: molecular and morphological evidence. Zoology. 2001; 103:157-78

29. Hansen T, Hansen J. First fossils of the isopod genus Aega Leach, 1815. J Paleontol. 2010;84:141-7

30. Nagler C, Haug C, Resch U, Kriwet J, Haug JT. 150 million years old isopods on fishes: a possible case of palaeo-parasitism. Bull Geosci. 2016;91:1-12

31. Hispano C, Bultó P, Blanch AR. Life cycle of the fish parasite Gnathia maxillaris (Crustacea: Isopoda: Gnathiidae). Folia Parasitol. 2014;61:277.

32. Brandt A, Poore GC. Higher classification of the flabelliferan and related Isopoda based on a reappraisal of relationships. Invertebr Syst. 2004;17:893-923.

33. Wilson GD. The phylogenetic position of the Isopoda in the Peracarida (Crustacea: Malacostraca). Arthropod Syst Phylogeny. 2009;67:159-98.

34. Serrano-Sánchez ML, Nagler C, Haug C, Haug JT, Centeno-García E, Vega FJ. The first fossil record of larval stages of parasitic isopods: cryptoniscus larvae preserved in Miocene amber. Neues Jahrb Geol Palaontol Abh. 2016:279:97-106.

35. Radwańska U, Poirot E. Copepod-infested Bathonian (Middle Jurassic) echinoids from Northern France. Acta Geol Pol. 2010:60:549-55.

36. Basso D, Tintori A. New Triassic isopod crustaceans from northern Italy. Palaeontology. 1995:37:801-10.

37. Feldmann RM, Wieder RW, Rolfe WI. Urda mccoyi (Carter 1889), an isopod crustacean from the Jurassic of Skye. Scott J Geol. 1994:30:87-9.

38. Polz H, Schweigert G, Maisch M. Two new species of Palaega (Isopoda: Cymothoida: Cirolanidae) from the Upper Jurassic of the. Palaeodiversity. 2006;362:1-17.

39. Brandt A, Crame J, Polz H, Thomson M. Late Jurassic tethyan ancestry of recent southern high-latitude marine isopods (Crustacea, Malacostraca). Palaeontology. 1999;42:663-75.

40. Etter W. A well-preserved isopod from the Middle Jurassic of southern Germany and implications for the isopod fossil record. Palaeontology. 2014;57:931-49.

41. Feldmann RM. A new cirolanid isopod (Crustacea) from the Cretaceous of Lebanon: dermoliths document the pre-molt condition. J Crust Biol. 2009;29:373-8.

42. Feldmann RM, Charbonnier S. Ibacus cottreaui Roger, 1946, reassigned to the isopod genus Cirolana (Cymothoida: Cirolanidae). J Crust Biol. 2011;31:317-9.

43. Gaillard C, Hantzpergue P, Vannier J, Margerard AL, Mazin JM. Isopod trackways from the Crayssac Lagerstätte, Upper Jurassic, France. Palaeontology. 2005:48:947-62.

44. Jones WT, Feldmann RM, Garassino A. Three new isopod species and a new occurrence of the tanaidacean Niveotanais brunnensis Polz, 2005 from the Jurassic Plattenkalk beds of Monte Fallano, Italy. J Crust Biol. 2014;34:739-53. 
45. Stolley E. Über zwie neue Isopoden aus norddeutschem Mesozoikum. Jber niedersächs Geol Ver. 1910;6:191-216.

46. Straelen VE. Contribution à l'étude des isopodes méso-et cénozïques. Mem Acad r Belg. 1928;9:1-66.

47. Taylor BJ. An urdidid isopod from the Lower Cretaceous of south-east Alexander Island. Brit Antarct Surv. 1972;27:97-103.

48. Frentzen K. Paläontologische Skizzen aus den Badischen Landessamlungen für Naturkunde, Karlsruhe i. Br. II. Mecochirus eckerti nov. spec. aus dem Lias Epsilon (Posidonienschiefer) von Langenbrücken. Carolinea. 1937;2:103-5.

49. Carter J. On fossil isopods, with a description of a new species. Geol Mag. 1889;6:193-6.

50. Remeš M. Urda moravica n. sp. z doggeru Chřibů. Acta Mus Moraviae Sci biol. 1912;12:173-7.

51. Münster G. Ueber einige Isopoden in den Kalkschiefern von Bayern. Beitr Petrefactenkunde. 1840;3:19-23.

52. Kunth A. Über wenig bekannte Crustaceen von Solnhofen. Ger J Geol. 1870; 22:771-802.

53. von Ammon JG. Ein Beitrag zur Kenntniss der vorweltlichen Asseln. Abh Math-Phys Kl, K Bayer Akad Wiss. 1882;12:507-50.

54. Büchner M. Eine fossile Meeresassel (Isopoda, Malacostraca) aus den Parkinsonienschichten (Mittlerer Jura) von Bethel, Kreis Bielefeld. Ber Nat wiss Ver Belef. 1971;20:27-35

55. Werner W. Urda sp. - Zwei Meeresasseln aus dem Mitteljura von Bielefeld. Mitt. Bayer. Staatssaml. Paläont hist Geol. 2012;40:39-42.

56. Grant-Mackie J, Buckeridge J, Johns P. Two new Upper Jurassic arthropods from New Zealand. Alcheringa. 1996;20:31-9.

57. Oppel A. Über jurassische Crustaceen. Mitt Bayer Staatssaml Paläont hist Geol. 1862;1:1-120.

58. Etter W. Isopoden und Tanaidaceen (Crustacea, Malacostraca) aus dem unteren Opalinuston der Nordschweiz. Eclogae Geol Helv. 1988;81:857-77.

59. Nagler C, Haug JT. Functional morphology of parasitic isopods: understanding morphological adaptations of attachment and feeding structures in Nerocila as a pre-requisite for reconstructing the evolution of Cymothoidae. PeerJ. 2016;4:e2188.

60. Haug C, Kutschera V, Ahyong ST, Vega FJ, Maas A, Waloszek D, Haug JT. Re-evaluation of the Mesozoic mantis shrimp Ursquilla yehoachi based on new material and the virtual peel technique. Palaeontol Electron. 2013;16:16.2.5T.

61. Haug C, Mayer G, Kutschera V, Waloszek D, Maas A, Haug JT. Imaging and documenting gammarideans. Int J Zoo. 2011;38:380829.

62. Haug C, Van Roy P, Leipner A, Funch P, Rudkin DM, Schöllmann L, Haug JT. A holomorph approach to xiphosuran evolution - a case study on the ontogeny of Euproops. Dev Genes Evol. 2012;222:253-68.

63. Simonetta AM, Delle CL. An essay in the comparative and evolutionary morphology of Palaeozoic arthropods. Accad Naz Lincei Rome. 1981;49: 389-439.

64. Bunkley-Williams L, Williams EH. Isopods associated with fishes: a synopsis and corrections. J Parasitol. 1998:84:893-6.

65. Monod T. Les Gnathiidae: essai monographique. Mém Soc Sci Nat Maroc. 1926:13:1-668

66. Günther K. Bau und Funktion der Mundwerkzeuge bei Crustaceen aus der Familie der Cymothoidae (Isopoda). Zoomorphology. 1931;23:1-79.

67. Brusca RC. A monograph on the Isopoda Cymothoidae (Crustacea) of the eastern Pacific. Zool J Linn Soc. 1981;73:117-99.

68. Coetzee ML, Smit NJ, Grutter AS, Davies AJ. Gnathia trimaculata n. sp. (Crustacea: Isopoda: Gnathiidae), an ectoparasite found parasitising requiem sharks from off Lizard Island, Great Barrier Reef, Australia. Syst Parasitol. 2009;72:97-112.

69. Davies AJ. A scanning electron microscope study of the praniza larva of Gnathia maxillaris Montagu (Crustacea, Isopoda, Gnathiidae), with special reference to the mouthparts. J Nat Hist. 1981;15:545-54.

70. Smit NJ, Basson L. Gnathia pantherina sp. n. (Crustacea: Isopoda: Gnathiidae), a temporary ectoparasite of some elasmobranch species from southern Africa. Folia Parasitol. 2002;49:137-51.

71. Jithendran K, Natarajan M, Azad I. Crustacean parasites and their management in brackishwater finfish culture. Aquac Mag. 2008;5:47-50.

72. Thatcher $V$. Mouthpart morphology of six freshwater species of Cymothoidae (Isopoda) from Amazonian fish compared to that of three marine forms, with the proposal of Artystonenae subfam. nov. Amazonia. 1997;14:311-22
73. Brusca RC, Wilson GD. A phylogenetic analysis of the Isopoda with some classificatory recommendations. Mem Queensl Mus. 1991;31:143-204.

74. Barthel K, Swinburne, NHM \& Conway Morris, S. Solnhofen. A Study in Mesozoic Palaeontology. Cambridge: Cambridge University Press; 1990.

75. Lester R. Isopoda. In: Rohde K, editor. Marine Parasitology. Collingwood: Csiro Publishing; 2005. p. 138-44.

76. Hansen HJ. Cirolanidæ et familiæ nonnullæ propinquæ musei Hauniensis: et bidrag til kundskaben om nogle familier af isopode krebsdyr. Naturvidenskabelig og Mathematisk Afdelning. 1890;5:237-426.

77. Rand TG. The histopathology of infestation of Paranthias furdfer (L.) (Osteichthyes: Serranidae) by Nerocila acuminata (Schioedte and Meinert)(Crustacea: Isopoda: Cymothoidae). J Fish Dis. 1986;9:143-6.

78. Poulin R. Evolutionary influences on body size in free-living and parasitic isopods. Biol J Linn Soc. 1995;54:231-44.

79. Hyžný M, Bruce NL, Schloegl J. An appraisal of the fossil record for the Cirolanidae (Malacostraca: Peracarida: Isopoda: Cymothoida), with a description of a new cirolanid isopod crustacean from the Early Miocene of the Vienna Basin (Western Carpathians). Palaeontology. 2013;56:615-30.

80. Hessler RR. Perarcarida. In: Morre RC, editor. Part R: Arthropoda, vol. 4. Kansas: Geological Society of America and University of Kansas Press; 1969. p. 360-93.

81. Menzies R. The zoogeography, ecology and systematics of the Chilean isopods. Acta Univ Lund. 1961;57:1-162

82. Wittler F. Bemerkungen zu "Palaega". Arbeitskreis Paläontologie Hannover. 2001;29:19-23.

83. Wetzer R, Perez-Losada M, Bruce NL. Phylogenetic relationships of the family Sphaeromatidae Latreille, 1825 (Crustacea: Peracarida: Isopoda) within Sphaeromatidea based on 18S-rDNA molecular data. Zootaxa. 2013;3599:161-77.

84. Kensley B. Guide to the marine isopods of southern Africa. Cape Town: South Africa Museum; 1978.

85. Brusca RC. A monograph on the isopod family Aegidae in the tropical eastern Pacific. Los Angeles: Allan Hancock Foundation; 1983.

86. Mockford EL. Some Psocoptera from plumage of birds. Proc Entomol Soc Washington. 1967;69:307-9.

87. Mockford EL. Psocoptera from sleeping nests of the dusky-footed wood rat in southern California. Pan-Pac Entomol. 1971;47:127-40.

88. Yoshizawa K, Johnson KP. How stable is the "polyphyly of lice" hypothesis (Insecta: Psocodea)?: A comparison of phylogenetic signal in multiple genes. Mol Phylogenet Evol. 2010;55:939-51.

89. Light JE, Smith VS, Allen JM, Durden LA, Reed DL. Evolutionary history of mammalian sucking lice (Phthiraptera: Anoplura). BMC Evol Biol. 2010;10:292.

90. Nagler C. (2017a). C_Nagler_20170221-M-130.1. www.morphdbase.de/?C_ Nagler_20170221-M-130.1.

91. Nagler, C. (2017b). C_Nagler_20170221-M-131.1. www.morphdbase.de/?C_ Nagler_20170221-M-131.1.

92. Cohen KM, Finney SC, Gibbard PL, Fan JX. The ICS international chronostratigraphic chart. Episodes. 2013;36:199-204.

\section{Submit your next manuscript to BioMed Central and we will help you at every step:}

- We accept pre-submission inquiries

- Our selector tool helps you to find the most relevant journal

- We provide round the clock customer support

- Convenient online submission

- Thorough peer review

- Inclusion in PubMed and all major indexing services

- Maximum visibility for your research

Submit your manuscript at www.biomedcentral.com/submit 